\title{
Lieutenant Colonel JF Donegan RAMC - Aeromedical Pioneer
}

\author{
Air Cdre T M Gibson \\ QHS, PhD,MB, ChB, MFOM, DAvMed, MRAeS, RAF \\ Director, Medical Programmes and Plans
}

Ministry of Defence, Main Building, Room 7360, Whitehall, London, SWIA $2 H B$.

\section{Introduction}

Despite claims that the French evacuated casualties out of Paris during the 1870 siege by balloon, there is no evidence that this ever happened (1). However, in 1913, a demonstration of the principles of aeromedical evacuation was carried out by "Colonel" Samuel Franklin Cody and Lieutenant Colonel JF Donegan RAMC at Laffan's Plain in Farnborough and this would appear to be the first record of such a subject being formally addressed. Cody was an American, but naturalised British in 1909, who had carried out the first authenticated powered flight in the United Kingdom in October 1908.

John Francis Donegan was born in Cork on 29 March 1863 and qualified LRCP and LRCS in Edinburgh, later advancing to
MRCS. Although the Army List gives his initials as JF, he $\frac{\vec{\sigma}}{\sigma}$ claimed the initials JDF in all his publications. As he was Irish, it $\underline{\underline{0}}$ is likely that he adopted his confirmation name as his middle $\frac{\bar{m}}{\vec{D}}$ initial.

He joined the Army as a surgeon in 1886 and saw service in Burma from 1887-1889, gaining a general service medal with $\vec{\circ}$ clasp. He then served again in Burma from 1889-1892, taking $\rightarrow$ part in the Poukan and Tonhon expeditions for which he was $\vec{\omega}$ awarded another clasp. He served on the North West Frontier from 1897-1898 for which he was awarded a medal and clasp $\stackrel{9}{3}$ and then in the South African War from 1899-1902. He took part ? in operations in Natal in 1899 including action at Talana. He was $\overrightarrow{\mathrm{f}}$ present at the defence of Ladysmith and had experience there of $\dot{c}$

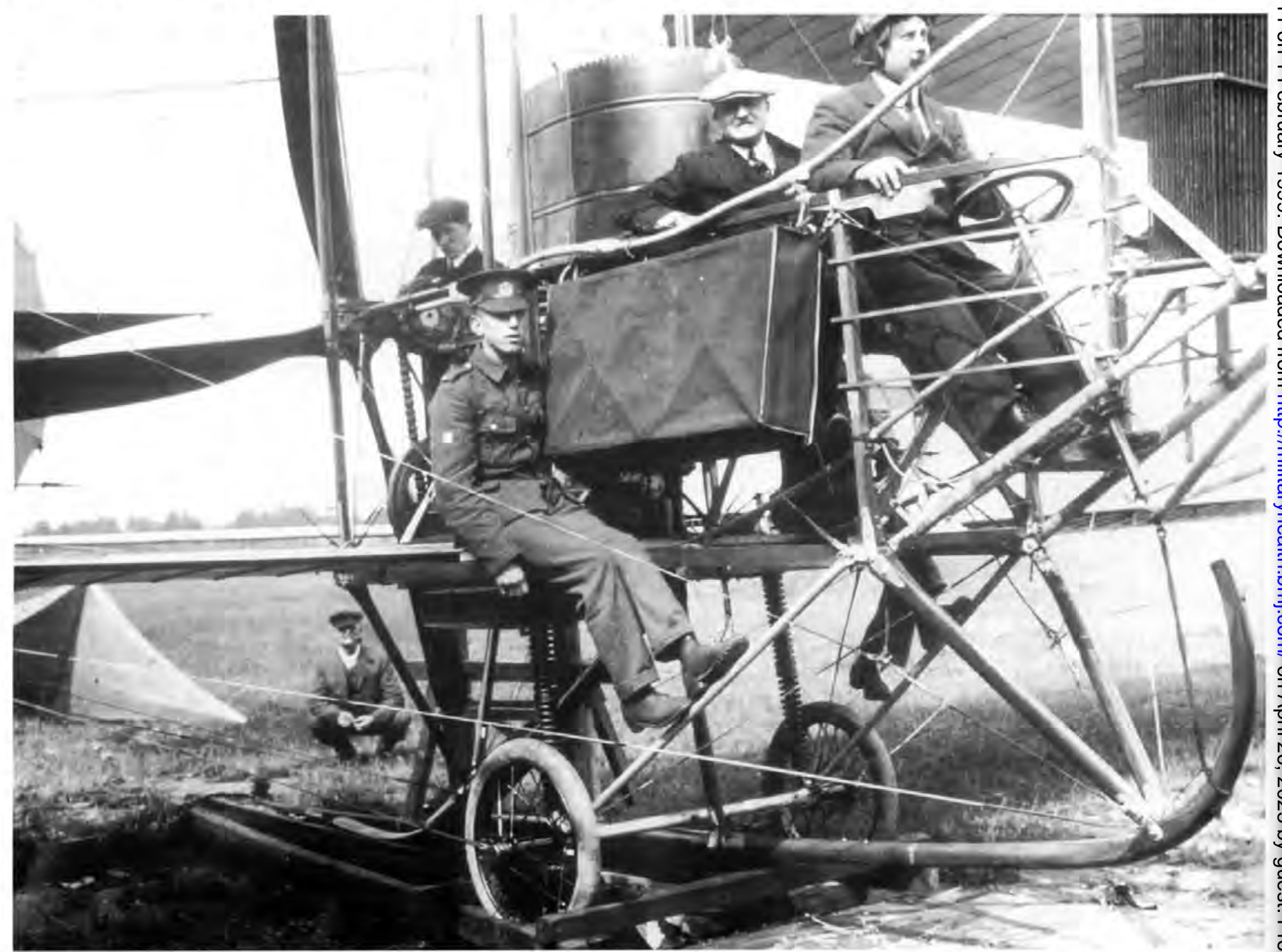

Fig 1. The Cody Waterplane, modified for use on land. Cody at the controls, his groom/handyman Charlie Phillips sitting immediately behind. Note that Cody is wearing what is probably the very first flying helmet which he may have designed himself. The man on the stepladder is Mr George Broomfield while the man squatting is Mr Sam Wackett (16). The soldier and his regiment are unidentified (personal communication, Army Historical Branch). He is wearing a drummer's arm badge. The field surgical kit and portable operating table is in the fabric covered box mounted in front of the soldier. The aircraft is resting on the sled that was used to pull it out of its shed sideways. 


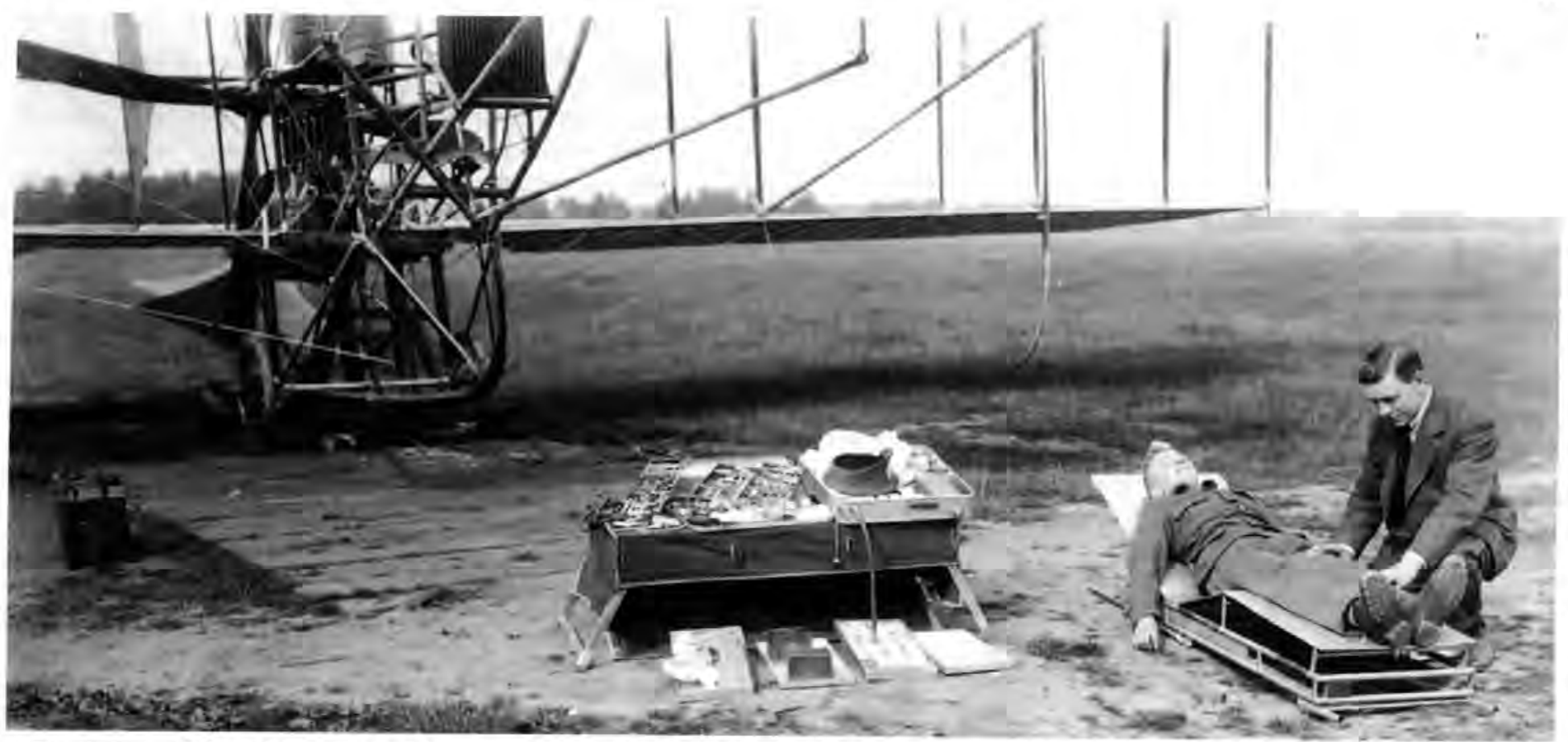

Fig 2. Examining the patient. Masquerading as a doctor is Mr George Broomfield, a parcels clerk at Aldershot Railway Station, who helped Cody in his spare time.

performing surgical operations in field conditions ("in a funk hole") for which he was mentioned in dispatches. He was also present at operations at Laing's Nek and the Zululand Frontier in Natal, and Reit Vlei and Lydenburg in the Transvaal. He finished the war with the Queen's Medal with 5 clasps and the King's Medal with 2 clasps (2). From 1902 to 1905, Donegan served in Ireland, following that with a 4 year tour of duty in Egypt. The years 1910-11 were spent at Parkhurst and this was followed by a tour at Woolwich.

By the time of Cody's demonstration, Donegan was better known as a song writer and reciter of his own poems. He had published 2 books of songs and poems in 1898 and $1912(3,4)$. By modern day standards, these contributions to literature would give doggerel a bad name. For example, an extract from his poem "Aerial Scouting. A prospect of the immediate future." runs as follows:

"The commandant mounts his flyer, and soars his force on high, Acquainting them with his orders: they've got to patrol the sky. To look for opposing forces; with keenness they're all endowed; They know that they must take cover behind any star or cloud." (5)

However, Donegan was aware of the potential that flying would bring to the practice of surgery during war. He prophesied that before many years passed, airships would replace ambulance trains for sitting cases and even possibly for more serious ones (6). He proposed in the same paper that aeroplanes could fly surgical assistance to severely wounded personnel and could even be used to evacuate the casualty (7). He was also aware that aeroplanes could not be monopolised for medical purposes, but could be tasked when necessary.

\section{Demonstration of Aeromedical Evacuation}

After his victory in the Army's military trials competition in 1912 with his Mk V flyer, Cody had spent 1913 preparing to launch his own company, Cody \& Sons Aerial Navigation Limited, and developing 2 new aeroplanes - a large monoplane to compete for the Daily Mail prize of $£ 10,000$ for the first transAtlantic flight and a biplane for use on water to participate in a round-Britain competition.

It was an early version of the waterplane that Cody used to demonstrate the principles of aeromedical evacuation in July 1913 (8). After buoyancy testing on a nearby canal in June, Cody had replaced the floats with an undercarriage for flight testing. The biplane was bigger than the Mk V Flyer, having a span of 60 feet $(18.6 \mathrm{~m})$, a length of $41 \mathrm{ft}(12.5 \mathrm{~m})$, a wing area of $770 \mathrm{sq} \mathrm{ft}$ $\left(72 \mathrm{~m}^{2}\right)$ and a total weight of over a ton. It was the largest aircraft built to date in the United Kingdom $(9,10)$. It had a 4 bladed, fixed pusher propeller driven by a 100 horsepower Green engine which gave a top speed of over $70 \mathrm{mph}$.

Since Donegan had not served in Aldershot, it is unlikely that Cody had met him when being checked over at the Connaught Hospital after one of his many flying accidents. It is more probable that Donegan had contacted Cody when he became aware of the potential for the use of aviation in adding support to deployed operations.

The demonstration took place on 14 July 1913 (after ground trials on 11 July) on Laffan's Plain at Farnborough in the northwest corner just outside Cody's shed and workshop. Either Donegan or Cody had obtained a young soldier to act as patient (Fig 1) but Donegan believed that Cody's aeroplane could carry up to 2 wounded men if required (7). The folding stretcher, which formed part of the box for the kit and doubled as an operating table, was not standard equipment. It was Donegan's invention (11) and the patent was held by the instrument makers Arnold \& Sons (12).

The rectangular case of the operating table extended to reveal drawers to carry surgical and anaesthetic equipment. The surface on which the patient lay was flat but could be hinged to provide an adjustable backrest to raise the head (Fig 2). Extensible handles allowed the table to be carried as a stretcher. The canvas covered box for the apparatus could be used as a separate side table to hold instruments while the instrument trays had folddown legs to allow a spirit lamp to be placed underneath to sterilise the instruments. Donegan had pared down the standard 5 cases and their contents then needed to perform an operation on the line of march (operating table, surgical panniers 1 and 2 , medical panniers 1 and 2). The total weight of his operating table was $47 \mathrm{lbs}$ into which could be packed $46 \mathrm{lbs}$ of equipment. The list of equipment carried is at Appendix 1.

The portable stretcher was taken from its case, placed on the 
APPENDIX 1

Contents of the Surgical Kit (4)
Apparatus, saline infusion

Calico, thin

Drainage tubing

Inhaler, Skinner's

Sterilizer, 1905 pattern

Silk Skeins, plaited

Tin of sodium chloride

Stovaine syringe

Gloves, rubber

Towels, aseptic

Cartons of chloroform tubes $(6 \mathrm{oz})$

Forceps, tongue

Stopcock for ethyl chloride tube

Gauze, D.C. compressed, $2_{1 / 2}$ yd packets

$27_{1 / 2}$ yds

Wool, C.A. compressed,

2 oz packets

Spirit lighter

Stethescope, aluminium

Soap cakes

Cloth, waterproof
No 1

4 yds

1 tube

6 pairs

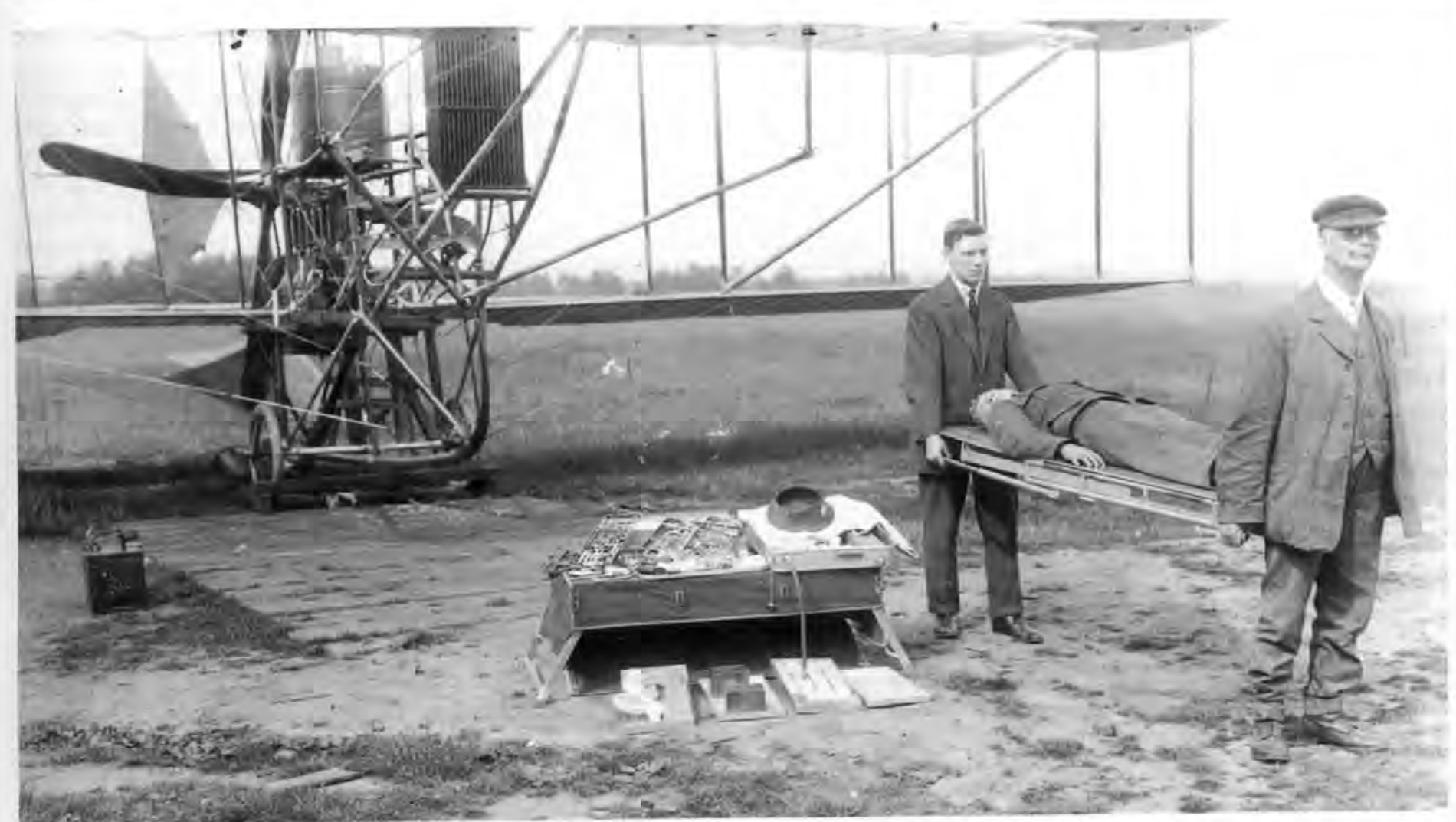

Fig 3. Preparing for evacuation. The petrol cans bear the legend "Shell Motor Spirit". ground and opened (Fig 3). The patient was tied firmly to the stretcher, and the stretcher and patient together were then tied to the middle of the upper wing. As the aircraft rotated for takeoff and climbed away in its usual steep manner, the stretcher and its occupant started slipping backwards, towards the pusher propeller. The terrified patient shouted out in alarm and managed to attract Cody's attention. Cody realised what first demonstration of aeromedical evacuation was brought to an abrupt end. The Times noted laconically that "Mr. S F Cody was happening and landed the aircraft at once (13). Thus the
No 1

No 1

1 tin

No 1

No 1

6

No 3

No 1

No 1

Bandages, loose woven

No 12

Containers, vulcanite (50 corrosive sublimate tabs)

Instruments, operation (surgeon's roll)

Pins, safety

Sterilizer, 1905 pattern, spirit container

1 set

2 boxes

Tin of soda

Tubes, iodine powder

Solution for cases

Surgical gauntlets

Case, hypo., ' 98 pattern

Drop bottle for chloroform (in leather covered case;

2 oz chloro.)

Tube, Ethyl chloride

Bandages, triangular

Wool, D.C. compressed, 2 oz packets

Sponges, abdominal

$1 / 2$ lb Tape, measuring (spring)

Field tourniquets

No 2

No 1

No 20

No 1

2 pairs

No 1

No 2

1 tube

No 6

$1 \mathrm{lb}$

No 6

No 1

No 4

No 4

No 4

$2 \mathrm{yds}$ made a first flight yesterday on his large biplane, which is eventually to be used for Army ambulance work" (14). Cody and Donegan remained enthusiastic over the potential for the aircraft and made arrangements for a doctor, nurses and the surgical kit to be flown from Laffan's Plain to Fox's Hill to give attention to "wounded soldiers" in an exercise. The local press christened the aircraft "The Angel of Mercy" (8).

Cody realised that the potential for aeromedical evacuation lay in developing an aeroplane with an enclosed cabin in which the patient and an attendant could be carried and he decided to 
build such an aeroplane once his attempts on the round Britain race and flying the Atlantic were over. Unfortunately, he was killed the following month on 7 August 1913 when the waterplane broke up in midair. Cody had been giving a friend a joyride before he flew to Calshot to test the airerti's sea capability.

Without easy access to any of the other developers of aeroplanes, there is no evidence that Donegan was able to progress his ideas further. He had, by mid-1913, been posted to Woolwich and was soon involved in the First World War where the static nature of the Flanders campaign rendered his ideas unnecessary. Donegan served in Mesopotamia and was mentioned 3 times in the same dispatch on 5 April 1916 and awarded a CB (military) in July 1916. He was placed on the retired list on 29 March 1918 and died in Fareham on 8 March 1934 (15). The first accepted aeromedical evacuation was carried out by the French in 1917 when they lifted an injured soldier out of Serbia (16).

\section{Acknowledgement}

Figures 1 to 3 are reproduced courtesy of the Defence Evaluation and Research Agency.

\section{REFERENCES}

1. LAM DM. To pop a balloon: aeromedical evacuation during the 1870 siege of Paris. Aviat Space Environ Med 1988. 59: 988-91.

2. Army List, 1905.
3. DONEGAN JDF. Digressions from Science, Camp-Fire Songs and How to Sing Them. Madras: Higgenbotham \& Co. 1898.

4. Donegan JDF. Rag Time. A Collection of Military Poems Suitable for Recitation. Lynwood \& Co., London: 1912.

5. Ibidem, pp. 46-7.

6. The Times, 24 July 1913, London. The Times actually misreported Donegan's name as Donegal.

7. DONEGAN JDF. The relation of and utility of aeroplanes in connexion with medical services in the field. $\mathrm{Br} \mathrm{Med} J 9$ Aug 1913; 1I: 304-5.

8. Gibson TM. Samuel Franklin Cody: Aviation and aeromedical evacuation pioneer. Aviat Space Environ Med (in the press).

9. The Times, 12 July 1913, London.

10. Sheldrake's Aldershot Military Gazette. Cody's Waterplane Flight. 18 July 1913.

11. Sheldrake's Aldershot Military Gazette. Cody's Flying Hospital. 25 July 1913.

12. DONEGAN JF \& ARNOLD JE. Improvements in and relating to operation tables. British Patent No. 4648, accepted 5 December 1912.

13. CoDY V. Missed losing his feet by inches. RAE News 1949 ; 2(1):3.

14. The Times, 13 July 1913, London.

15.RAMC News d Gazelte, 1934; 7(10): 316.

16. Broomfield GA. Pioneer of the Air. London: Gale \& Polden, 1953. 